\title{
A Framework for Cultivating Students' Spirituality \& Skills Employers Demand at a Public Institution
}

\author{
Shannon Nolan-Arañez, Marilee Bresciani Ludvik \\ Department of Administration, Rehabilitation, and Post Secondary Education, San Diego State University, San Diego, California, \\ USA \\ Email: snolan@csusm.edu
}

How to cite this paper: Nolan-Arañez, S., \& Ludvik, M. B. (2017). A Framework for Cultivating Students' Spirituality \& Skills Employers Demand at a Public Institution. Open Journal of Leadership, 6, 104-111. https://doi.org/10.4236/ojl.2017.63007

Received: June 25, 2017

Accepted: August 7, 2017

Published: August 10, 2017

Copyright @ 2017 by authors and Scientific Research Publishing Inc. This work is licensed under the Creative Commons Attribution International License (CC BY 4.0).

http://creativecommons.org/licenses/by/4.0/

\section{(c) (i) Open Access}

\begin{abstract}
Postsecondary education is expected to develop college graduates who are prepared to solve global issues using values' judgment (Shahid, 2015; Welsh, 2014). As such, we explored whether spiritual development cultivates the skills that employers demand through the theory of self-authorship (Pawar, 2014; Wolde, Groenendall, Helsloot, \& Welsh, 2014). The findings of our synthesis of literature suggest a model where educators may integrate spiritual development activities into their co-curricular leadership development programs. Through meaningful learning experiences, students can gain insight into their values and understand their role in solving global problems (National Association of Colleges and Employers, 2014, 2016; Pawar, 2014; Wolde, Groenendall, Helsloot, \& Welsh, 2014).
\end{abstract}

\section{Keywords}

Spiritual Development, Leadership Development, Self-Authorship, Employable Skills

\section{Introduction}

Students enter college during a transformative time of life where they are becoming more independent and constructing their own realities (Parks, 2000). College tests the spirit through personal reassessment, experimentation, adjustment, exploration, and risk (Kuh, Cruce, Shoup, Kinzie, \& Gonyea, 2008). Research supports the notion that spirituality fosters self-awareness (Ahren, 2009; Gehrke, 2008; Walker \& McPhail, 2009) and one's ability to entertain, discern, and synthesize diverse ideas and make meaning of the world (Burch, Heller, \& 
Freed, 2014; Gibson, 2014; Astin, 2003). This manuscript describes how spirituality is defined by contemporary literature. We posit that spirituality is fostered by students' achievement of self-authorship (Magolda, 2009), a theoretical framework by which students develop, take responsibility for building their internal voice, and express authenticity by trusting their internal voices. We then relate spirituality and self-authorship to leadership development program activities and how these activities may influence the students' preparedness to solve global issues using values' judgment.

\section{Spirituality Defined}

Contemporary definitions of spirituality posit that spirituality is rooted in human consciousness and how an individual forms meaningful connections to others and a sacred being, sometimes referred to as "God", "Great Spirit" or "Universal Light” (Astin, 2004; Astin \& Keen, 2006; Benefiel, 2005; Tisdell, 2001, 2007; Rockenbach et al., 2015; Tisdell, 2001, 2006). On a more individualized humanistic level, spirituality has also been defined as one's ability to process a higher sense of self in relation to a community through the creation and expression of knowledge (Fry \& Cohen, 2009; Love \& Talbot, 2000). Specifically, Astin (2004) and Palmer (1996) describe spirituality as an inward quest for connection to something greater-one's private, subjective, internal domain, involving one's emotional experiences as well as their values and beliefs. Spiritual development has been analogous to moral and personal development (Fowler, 1981; Kegan, 1982) and although some students may include their religion in their definition, the term spirituality has a variety of meanings to the many different people who seek it (Astin, 2004; Brimhall-Vargas \& Clarke, 2008; Gehrke, 2008; Rockenbach, Mayhew, Davidson, Ofstein, \& Bush, 2015).

Through the lens of student development theory, spirituality may be the essence of how students make meaning of their internal world and world around them through self-discovery (Astin \& Keen, 2006; Magolda, 2003, 2009; Brimhall-Vargas \& Clarke, 2008; Gehrke, 2008; O’Neill, 2014; Reave, 2005; Tisdell, 2001, 2003, 2006). Students who practice self-reflection are more likely to accept others from different creeds and traditions which can ultimately change the cultural and moral fabric of our nation to a more compassionate, unified, inclusive society (Dalton, 2001; Kunzman, 2006; O’Neill, 2014). According to Tisdell (2003), spirituality is the sacred understanding that we are part of a greater "oneness" or force. Dalton, Eberhardt, Bracken, \& Echols, (2006) define spirituality as an inward journey or quest to find one's purpose, meaning, wholeness, and authenticity.

\subsection{Theoretical Framework: Self-Authorship \& Spirituality}

The internal capacity to construct meaning is related to what Magolda (2009, 2014) calls self-authorship. Self-authorship is a metacognition, of understanding one's beliefs, relationships, and identity (Karp \& Bork, 2012; Duckworth, Akerman, MacGregor, Salter, \& Vorhaus, 2009). Self-authorship suggests a more evolutionary process in which young people begin to "renegotiate the relation- 
ship of their internal voices and external influence" (Magolda, 2009: p. 324). Students progress through three developmental phases cognitive development, intrapersonal development, and intrapersonal development, as indicated by the purple, pink, and green squares on Figure 1 achieved by listening to and cultivating their internal voice or their insight into a situation. The internal voice may be referred to as the Mind or the "awareness that arises when you are aware that you are integrating your senses, thoughts, emotions, and intuition" (Bresciani Ludvik, Wolff, \& Henning, 2016: p. 82). Inner beliefs and identity are expressed in this internal voice and guide our behavior (Magolda, 2009). Such inner beliefs and identify may take into account predispositions, personality, and past experiences (Magolda, 2009; Collins, 2007). The journey of self-authorship is a journey toward deep understanding of the "internal coordination of beliefs, identities, and social relations" (Magolda, 2014: p. 27).

As Figure 1 illustrates, students' progression through self-authorship may be analogous to their spiritual development in that both spirituality and self-authorship are inward journeys which expand understandings of self, influence personal growth and self-awareness as students navigate through life's challenges. Spiritual development expands and quickens as students make meaning of their experiences and the world around them (Astin, 1999; Astin \& Keen, 2006; Gehrke, 2008; Tisdell, 2001). One way that this is accomplished is through

Moving Toward Self-Authorship:

- Crossroads Emergence: Listening to the Internal Voice

- Quieting external forces through reflection
Cognitive Development

Building a Self-Authored System:

- Securing internal commitment

- Taking action and solving

problems

- Building relationships with others

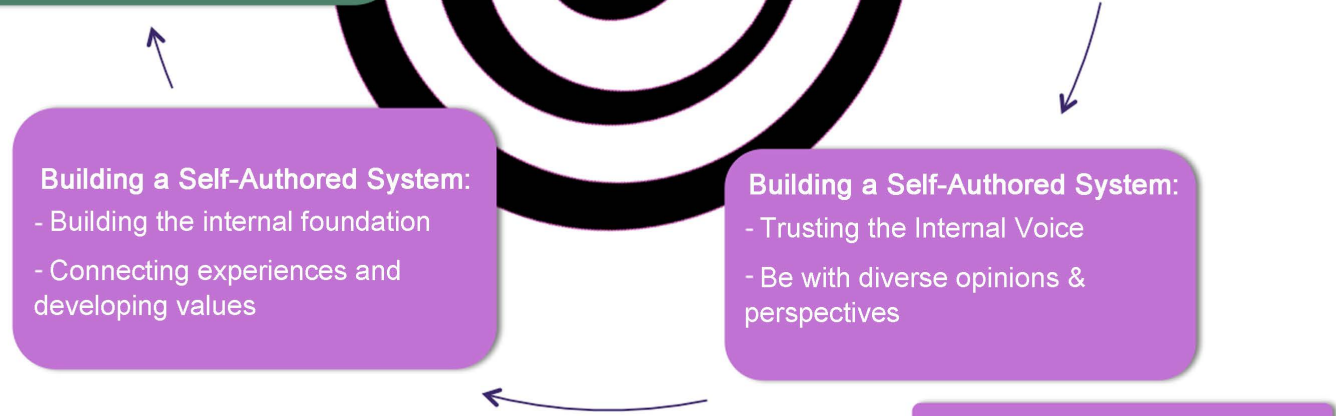

Intrapersonal Development

Figure 1. Model of spiritual development through the theory of self-authorship. 
self-reflection during crossroad experiences (e.g., experiences which challenge and expand perspective). As students move from listening to cultivating their internal voice, they begin to critically analyze the direction of their lives and who they are as unique individuals (Magolda, 2009).

The second phase of self-authorship involves "Building a Self-Authored System" (Magolda, 2009: p. 325) where students explore new ideas and realize how they view themselves. Magolda (2009) refers to this as intrapersonal development that is deciding how we shape our identities to reflect our authentic internal voice. Students may decide to let go of expectations set upon them by family members and to explore new campus experiences to shape their identity. The final stage of self-authorship is interpersonal development which requires students understanding how they want to interact with others, how to determine expectations for loved ones and others in our lives. The cycle of self-authorship builds momentum with every crossroads experience (a point in time) where students decide if they want to move forward with others' expectations or in a new direction informed by their internal voice. As the spiral suggests, spirituality and self-authorship are dynamic; they can expand and contrast based on life's experiences and the human reaction to them. Neither spirituality nor self-authorship has a clear beginning or end; both evolve over time.

\subsection{Fostering Spirituality through Leadership Activities}

Chickering et al. (2006) posit that learner-oriented pedagogy gives students the time and space for deep learning (e.g., self-reflection and the ability to discern information). The art of personal reflection is a universal practice that any discipline could adopt to foster deep learning. Activities that guide students through self-reflection and critical discussion discerning prior attitudes and emotional reflexes foster meaning making (Chickering et al., 2006). Interestingly, critical reflection is one of several contemplative practices and can be used to guide students through self-authorship, thus also fostering spiritual development (Magolda, 2009; Underwood \& Teresi, 2002). Neuroscience research provides empirical evidence that insight reflection or a focus on the inner life increases attention, decreases stress, and can increase compassion promoting peaceful relationships (Bresciani Ludvik et al., 2016). Specific training can allow students to focus their attention on demand, regulate emotions often associated with something that is different from self, thus allowing integration of all aspects of perceptions of self and life experience into learning and development (Bresciani Ludvik et al., 2016). Creating opportunities for students to apply relevance of their educational experiences to their lives by creating space for reflection may allow them to feel more deeply, experiencing themselves as co-creators in their learning (Barbezat \& Bush, 2014; Magolda, 2009).

Engagement in leadership activities usually includes self-assessment and reflection to promote development of higher-level learning and self-awareness

(Kuh, Cruce, Shoup, Kinzie, \& Gonyea, 2008). Results from a study by Cress, Astin, Zimmerman-Oser \& Burkhardt's (2001) showed significant growth in 
leadership capacity, social responsibility, multicultural awareness, and understanding of personal and societal values through participating in student organizations and leadership programs. These outcomes mirror those found when cultivating spirituality (Brimhall-Vargas \& Clark, 2008; Dent, Higgins, \& Wharff, 2005; Walker \& McPhail, 2009).

Leadership programs also offer students the opportunity to gain self-confidence and increased comfort with risk taking (Gallagher, Marshall, Pories, \& Daughety, 2014) through sociocultural discussions (Antionio, 2001; Ingleton, 2013), and community service (Astin \& Sax, 1998; Avalos, Sax, \& Astin, 1999; Dugan \& Komives, 2010). Student development theory posits that student success lies in the development of skills, learning, and self-development that honors one's uniqueness while challenging students to look beyond the self into the community to effect change (Amall, Johnson, Lee, Linder, Lund, \& Satpathy, 2014). Global leaders and employers agree that student success is achieved by preparing students to be good citizens and learning to serve the greater good (Ingleton, 2013).

Hence, similar to spiritual development, self-authorship is a process, which can be cultivated through leadership activities to develop students' spiritual development (Collins, 2007; Magolda, 2009, 2014; Posner, 2009) which has no clear beginning or end. Self-authorship is a theory which may foster spirituality and it may be that leadership development programs are a vehicle through which both self-authorship and spiritual development take place. Such possibilities for fostering self-authorship and spiritual development may exist in other programs as well, such as peer mentoring, residence halls, study abroad programs, and student organizations. Such programs often intend to help students learn and practice authentic leadership. Leadership, just like spirituality, occurs over time and expands or contracts based on practice in real-world settings (Gallagher, Marshall, Pories, \& Daughety, 2014; Kouzes \& Posner, 2006). Leadership identity can be integrated into one's self-identity through consistent self-reflection (Raffo, 2012).

\section{Conclusion}

In closing, our synthesis of literature connects self-authorship theory to foster spiritual development. As Figure 1 illustrates, spiritual development is the alchemy between cognitive, intrapersonal, and interpersonal developments and is where students learn how to quiet external influences through reflection, be with diverse perspectives through interaction with diverse individuals and situations, and to connect their experiences to develop their values by taking action and solving problems. Co-curricular programs often provide students with the crossroads experience, something challenging and new, such as leadership programs, peer advising, resident advising, and student organizations, allow students to take action and build relationships with others (interpersonal development) so that they can build a self-authored system. Hence, spirituality may be an unintended, yet an important outcome of co-curricular programs grounded in 
self-authorship; this supports the notion that spirituality may be intentionally fostered during college.

\section{References}

Ahren, C. S. (2009). Disentangling the Unique Effects of Co-Curricular Engagement on Self-Reported Student Learning Outcomes. Doctoral Dissertation, Bloomington: Indiana University.

Astin, A. W. (1999). Student Involvement: A Developmental Theory for Higher Education.

Astin, A. W. (2003). Studying How College Affects Students: A Personal History of the CIRP. About Campus, 8, 21-28.

Astin, A. W. (2004). Why Spirituality Deserves a Central Place in Liberal Education. Liberal education, 90, 34-41.

Astin, A. W., \& Keen, J. P. (2006). Equanimity and Spirituality. Religion and Education, 33, 39-46. https://doi.org/10.1080/15507394.2006.10012375

Benefiel, M. (2005). The Second Half of the Journey: Spiritual Leadership for Organizational Transformation. The Leadership Quarterly, 16, 723-747. https://doi.org/10.1016/j.leaqua.2005.07.005

Bresciani Ludvik, M., Wolff, R. A., \& Henning, G. W. (Eds.) (2016). The Neuroscience of Learning and Development: Enhancing Creativity, Compassion, Critical Thinking, and Peace in Higher Education. An ACPA/NASPA Joint Publication.

Brimhall-Vargas, M., \& Clark, C. (2008). Diversity Initiatives in Higher Education: Implications of Spirituality in Multicultural Curricular, Pedagogical, and Research Paradigms. Multicultural Education, 15, 54.

Burch, G. F., Heller, N. A., \& Freed, R. (2014). Back to the Basics: Developing a Student Engagement Survey to Evaluate the Role of Experiential Learning on Student Engagement. Developments in Business Simulation and Experiential Learning, 44, 41.

Collins, J. (2007). The Neuroscience of Learning. The Journal of Neuroscience Nursing: Journal of the American Association of Neuroscience Nurses, 39, 305. https://doi.org/10.1097/01376517-200710000-00008

Dalton, J. C. (2001). Career and Calling: Finding a Place for the Spirit in Work and Community. New Directions for Student Services, 2001, 17-25. https://doi.org/10.1002/ss.19

Dalton, J. C., Eberhardt, D., Bracken, J., \& Echols, K. (2006). Inward Journeys: Forms and Patterns of College Student Spirituality. Journal of College and Character, 7. https://doi.org/10.2202/1940-1639.1219

Duckworth, K., Akerman, R., MacGregor, A., Salter, E., \& Vorhaus, J. (2009). Self-Regulated Learning: A Literature Review. [Wider Benefits of Learning Research Report No. 33]. London: Centre for Research on the Wider Benefits of Learning, Institute of Education, University of London.

Fowler, J. W. (1981). Stages of Faith: The Psychology of Human Development and the Quest for Meaning. San Francisco, CA: Harper Collins.

Fry, L. W., \& Cohen, M. P. (2009). Spiritual Leadership as a Paradigm for Organizational Transformation and Recovery from Extended Work Hours Cultures. Journal of Business Ethics, 84, 265-278. https://doi.org/10.1007/s10551-008-9695-2

Gehrke, S. J. (2008). Leadership through Meaning-Making: An Empirical Exploration of Spirituality and Leadership in College Students. Journal of College Student Develop- 
ment, 49, 351-359. https://doi.org/10.1353/csd.0.0014

Gibson, A. (2014). Principals' and Teachers' Views of Spirituality in Principal Leadership in Three Primary Schools. Educational Management Administration \& Leadership, 42, 520-535. https://doi.org/10.1177/1741143213502195

Karp, M. J. M., \& Bork, R. J. H. (2012). “They Never Told Me What to Expect, So I Didn't Know What to Do": Defining and Clarifying the Role of a Community College Student. Community College Research Center Columbia University, 116, 47.

Kuh, G. D., Cruce, T. M., Shoup, R., Kinzie, J., \& Gonyea, R. M. (2008). Unmasking the Effects of Student Engagement on First-Year College Grades and Persistence. The Journal of Higher Education, 79, 540-563. https://doi.org/10.1353/jhe.0.0019

Love, P., \& Talbot, D. (2000). Defining Spiritual Development: A Missing Consideration for Student Affairs. NASPA Journal, 37, 361-375. https://doi.org/10.2202/1949-6605.1097

Magolda, M. (2009). Authoring Your Life. Developing an Internal Voice to Navigate Life's Challenges. Sterling, Virginia: Stylus.

Magolda, M. B. (2003). Identity and Learning: Student Affairs' Role in Transforming Higher Education. Journal of College Student Development, 44, 231-247. https://doi.org/10.1353/csd.2003.0020

Magolda, M. B. (2014). Self-Authorship. New Directions for Higher Education, 2014, 25-33. https://doi.org/10.1002/he.20092

Magolda, M. B. B. (2014). Students' Epistemologies and Academic Experiences: Implications for Pedagogy. College Student Development and Academic Life: Psychological, Intellectual, Social and Moral Issues, 15, 117.

National Association of Colleges and Employers (2014). Job Outlook (In Italics) (Infographic). http://www.naceweb.org

National Association of Colleges and Employers (2016). Job Outlook (In Italics) (Infographic). http://www.naceweb.org

O’Neill, K. B. (2014). Changing Places: Narratives of Spiritual Conversion during the First College Year. Ph.D. Thesis, Bowling Green, OH: Bowling Green State University.

Palmer, P. J. (1996). Leading from within. Noetic Sciences Review, 40, 32.

Parks, S. D. (2000). Big Questions, Worthy Dreams: Mentoring Young Adults in Their Search for Meaning, Purpose, and Faith. San Francisco, CA: Jossey-Bass.

Pawar, B. S. (2014). Leadership Spiritual Behaviors toward Subordinates: An Empirical Examination of the Effects of Leader's Individual Spirituality and Organizational Spirituality. Journal of Business Ethics, 122, 439-452. https://doi.org/10.1007/s10551-013-1772-5

Reave, L. (2005). Spiritual Values and Practices Related to Leadership Effectiveness. The Leadership Quarterly, 16, 655-687. https://doi.org/10.1016/j.leaqua.2005.07.003

Rockenbach, A. N., Mayhew, J. M., Davidson, J., Ofstein, J., \& Bush, R. C. (2015). Complicating Universal Definitions: How Students of Diverse World Views Make Meaning of Spirituality. Journal of Student Affairs Research and Practice, 52, 1-10. https://doi.org/10.1080/19496591.2015.996058

Tisdell, E. (2001). Spirituality in Adult and Higher Education. Eric Digest on Adult Career and Vocational Education, 232, 1-8.

Tisdell, E. (2003). Exploring Spirituality and Culture in Adult and Higher Education. San Francisco, CA: Jossey-bass.

Tisdell, E. (2007). In the New Millennium: The Role of Spirituality and the Cultural Im- 
agination in Dealing with Diversity and Equity in the Higher Education Classroom. Teachers College Record, 109, 531-560.

Tisdell, E. J. (2006). Spirituality, Cultural Identity, and Epistemology in Culturally Responsive Teaching in Higher Education. Multicultural Perspectives, 8, 19-25. https://doi.org/10.1207/s15327892mcp0803_4

Walker, M. W., \& McPhail, C. J. (2009). Spirituality Matters: Spirituality and the Community College Leader. Community College Journal of Research and Practice, 33, 321345. https://doi.org/10.1080/10668920802565011

Wolde, A., Groenendall, J., Helsloot, I., \& Schmidt, A. (2014). An Explorative Study on the Connection between Ethical Leadership, Prototypically and Organizational Misbehavior in a Dutch Fire Service. International Journal of Leadership Studies, 8, 18-43.

\section{Scientific Research Publishing}

Submit or recommend next manuscript to SCIRP and we will provide best service for you:

Accepting pre-submission inquiries through Email, Facebook, LinkedIn, Twitter, etc. A wide selection of journals (inclusive of 9 subjects, more than 200 journals)

Providing 24-hour high-quality service

User-friendly online submission system

Fair and swift peer-review system

Efficient typesetting and proofreading procedure

Display of the result of downloads and visits, as well as the number of cited articles

Maximum dissemination of your research work

Submit your manuscript at: http://papersubmission.scirp.org/

Or contact ojl@scirp.org 